\title{
TRACTUS STELLAE: THE “IMAGE” OF THE VIRGIN WITH THE CHILD IN THE ZAGREB CATHEDRAL FROM THE $11^{\text {TH }} / 12^{\text {TH }}$ CENTURY
}

\author{
Milan Pelc
}

\author{
M. Pelc \\ Institut za povijest umjetnosti \\ Ul. grada Vukovara 68 \\ HR-10000 Zagreb \\ Email: mpelc@ipu.hr
}

\begin{abstract}
In the oldest book of pontifical rites (Agenda pontificalis) of the Zagreb Cathedral, dated back to the late $11^{\text {th }}$ century, two liturgical plays were recorded. One of them is Tractus stellae, considered to be, in general, among historically most important liturgical dramas of its kind in the Western tradition of liturgical worship and church performances. The play has missed the attention of art historians, despite the fact that it contains a mention of an "image" (imago) of the Virgin with the Child as one of its key theatrical props. This paper will briefly summarize the previous proposals for the reconstruction of the church interior and its stage props. Also, by providing a commentary of those proposals it will then indicate possible features of the church interior and the aforementioned "image" which, based on the knowledge of art-historical and other relevant sources, can be assumed to have been present in the Zagreb church of the late $11^{\text {th }}$ and then also the $12^{\text {th }}$ century.
\end{abstract}

Key words: Agenda pontificalis Zagreb, Tractus stellae, Image of the Virgin with the Child, Sedes sapientiae

In the oldest book of pontifical rites (Agenda pontificalis) of the Zagreb Cathedral, dated back to the late $11^{\text {th }}$ century, two liturgical plays as components of worship services for the two biggest Christian feasts - Easter and Christmas (Epiphany) were recorded. ${ }^{1}$ Such liturgical plays were widespread in almost all the countries of Western Europe from the $11^{\text {th }}$ century onwards. According to most researchers, liturgical plays contained in the Zagreb's Pontifical were of French provenance and they were edited by Benedictines from Hungarian monasteries, who themselves were associated with the French Benedictine abbeys. ${ }^{2}$ Although, in the opinion of most researchers, the Pontifical was

\footnotetext{
${ }^{1}$ The codex (Bibliotheca Metropolitana, shelf number MR 165) has usually been referred to in literature as Missale antiquissimum or Agenda Pontificalis, more recently also as Ordo ecclesiae; parchment, Carolingian minuscule, 120 folios, 228 x $295 \mathrm{~mm}$; binding: wooden tablets fastened by straps, leather spine (restored around 1982); It was mentioned in the inventory of the Zagreb cathedral from the beginning of the $15^{\text {th }}$ c. $-c f$. I. K. TKALČIĆ, Povjestni spomenici slo. kralj. grada Zagreba, Vol. 11, Zagreb 1905, p. 133 and A. LUKINOVIĆ, Najstariji sačuvani imovnik zagrebačke katedrale (1394), in Croatica christiana periodica, 9 (1982) p. 67. For the origin, appearance and the content description of the codex, see: G. MORIN, Manuscrits liturgiques hongrois des XI' et XII ${ }^{e}$ siècles, in Jahrbuch für Liturgiewissenschaft, Münster, 6 (1926.), p. 54-60; A. MARKOV, Katalog Metropolitanskih riedkosti, in Zbornik Zagrebačke nadbiskupije u spomen 850. godišnjice osnutka, Zagreb, 1944, Part I, 520; D. KNIEWALD, Zagrebački liturgijski kodeksi XI. do XV. stoljeća, in Croatia Sacra. Arhiv za crkvenu povijest Hrvata, Zagreb 19 (1940), p. 7-12; D. KNIEWALD, Iluminacija i notacija zagrebačkih liturgijskih rukopisa, in Rad HAZU, Book 279 (1944), p. 20-21 - description of the notation. Both liturgical plays were first analysed, in a comprehensive and comparative manner, by F. FANCEV, Liturgijsko-obredne igre u zagrebačkoj stolnoj crkvi (prilog istoriji kulture u posavskoj Hrvatskoj XII. stoljeća), in Narodna starina, 10 (1925.), p. 1-16.

${ }^{2}$ This hypothesis was elaborated by F. FANCEV, op. cit., p. 13, who pointed to similarities between the Zagreb and several French versions of the liturgical play Tractus stellae (particularly the one from Rouen), without neglect-
} 


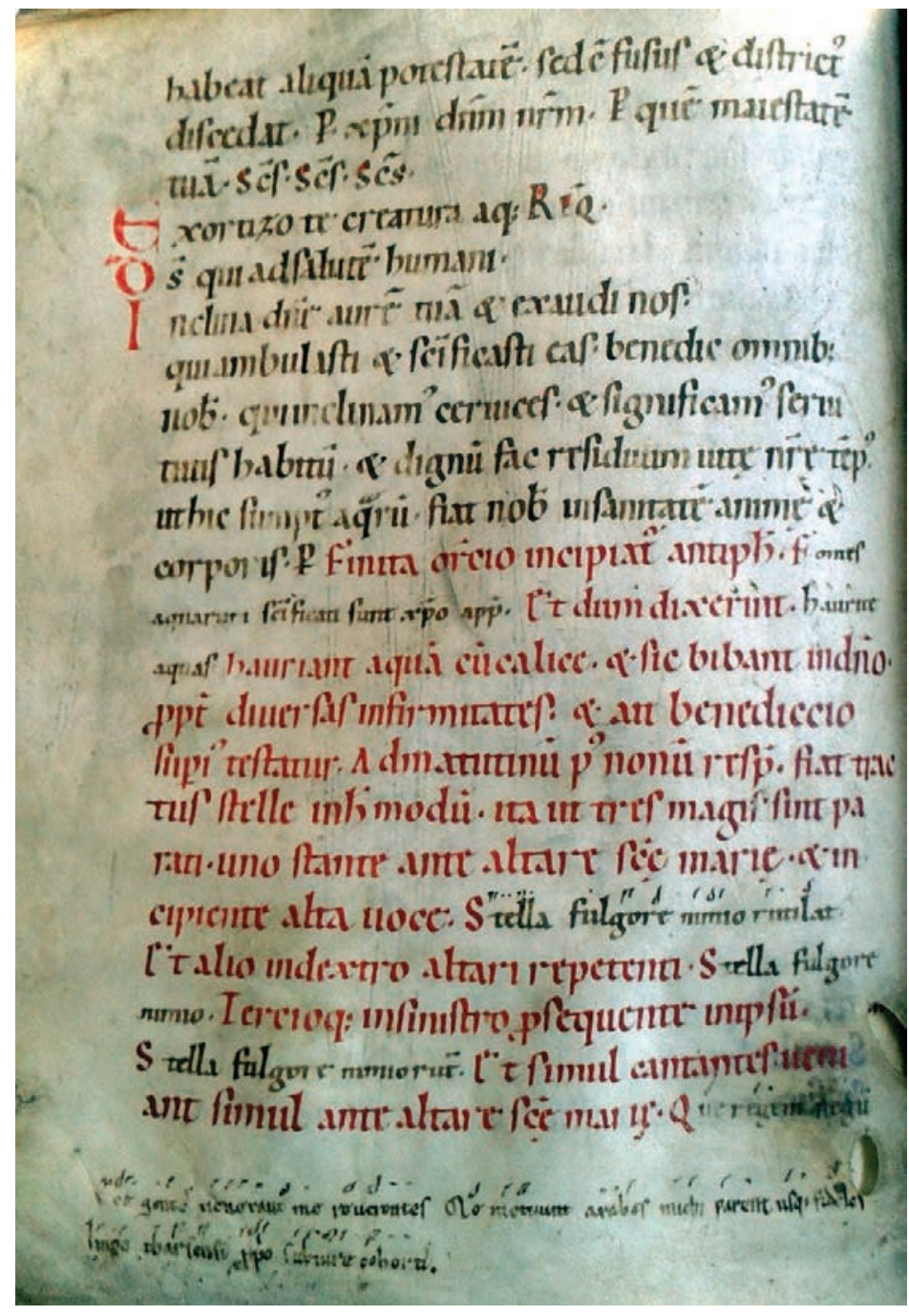

Fig. 1. Agenda Pontificalis, Tractus stellae, folio 28b, Bibliotheca Metropolitana, MR 165 originally written for Bishop Arduin or Hartvik from Győr in western Hungary, it was brought to Zagreb after the founding of the Zagreb Diocese, around 1094. ${ }^{3}$ It is assumed that it arrived to the newly-established diocese together with St. Margaret Sacramentarium (MR 126) and Benedictionale (MR 89) - two fundamental books for the performance of rites and episcopal functions in the Zagreb Cathedral. ${ }^{4}$ Regardless of the origin of the codex, most important for us here is the fact accepted by all researchers, namely that the codex is among the oldest that were used in the Zagreb's church - in all likelihood, from the very establishing of the diocese..$^{5}$ This means that the two liturgical plays were also performed in the Zagreb Cathedral already in those early days. It is worth mentioning that a fragment of yet another liturgical play, known as Ordo prophetarum, was also found in Zagreb. It is believed that this play was written in the late $12^{\text {th }}$ or early $13^{\text {th }}$ century - approximately a hundred years after the two liturgical plays that are contained in the Agenda pontificalis. ${ }^{6}$ The performance of those liturgical plays - as the "theatrical" components of the worship service of the Zagreb church were abolished, it seems, by Bishop Au-

ing similarities with two German versions either. The Zagreb variant in this respect is a sort of amalgamation, but with its own character.

${ }^{3}$ The name of bishop Hartwig (Hartwick, Chartvirgus, Arduin), which was later partially deleted, had been recorded in Exultet, on folio 84. The thesis that bishop Hartwig (Arduin) was the first commissioner of the codex was put forward by G. MORIN, op. cit. p. 57, and it was accepted by D. KNIEWALD, Zagrebački liturgijski kodeksi XI. do XV. stoljeća, in Croatia Sacra. Arhiv za crkvenu povijest Hrvata, Zagreb 19 (1940), p. 7-12.

${ }^{4}$ In a more recent time, M. DEMOVIĆ, Obredna drama u srednjovjekovnim liturgijsko-glazbenim kodeksima u Hrvatskoj, in Dani Hvarskog kazališta 2, Split, 1985, p. 242-292, proposed, based on several contentwise and liturgical arguments, a completely new theory that the codex was not at all written for the Hungarian church in Győr, but rather for the Cathedral of St. Anastasia in Zadar, which is why he called it "Ordo ecclesiae cathedralis Sanctae Anastasiae". Although the Dalmatian origin of the Pontifical can not be entirely excluded, his arguments have a few unconvincing points, for instance the interpretation aimed at refuting bishop Hartwig (Arduin) from Györ as the commissioner of the book. On this, cf. R. KATIČIĆ, Literarum studia. Književnost $i$ naobrazba ranoga hrvatskog srednjovjekovlja, Zagreb, 1998, p. 612.

${ }^{5}$ More recently, the Zagreb Pontifical was interpreted as a direct derivative of the "proto-pontifical" of the 11th century's Esztergom Archdiocese, which at that time had a primacy among the Hungarian dioceses, including that of Zagreb. Cf. M. I. FÖLDVÁRY, Rubrica Strigoniensis. A középkori Esztergom liturgiájänak normaszövegei. $\mathrm{PhD}$ thesis, Budapest, 2008, p. 11 (Summary). In this case, the liturgical play Tractus stellae is also directly associated with the tradition of the $11^{\text {th }}$ century Esztergom, which itself was influenced by various sources, including the French ones. ${ }^{6}$ Liturgical play Ordo prophetarum, found in the collection Collectio fragmentorum (no. 1) of the Metropolitan Library Archives, was published and revised, along with the two other liturgical plays, by M. DEMOVIĆ, op. cit., 
gustin Kažotić when he reformed the church ceremony of the Zagreb diocese at the beginning of the $14^{\text {th }}$ century. ${ }^{7}$

Of the three Zagreb texts that belong to the genre of the medieval liturgical drama, the most extensive and complex is the Epiphany play of the Three Kings, Tractus stelle. ${ }^{8}$ Some dialogs of the Tractus stellae are neumatically notated, i.e. they are marked with indications about how they should be sung, which is almost surely a proof that the pious play was performed in a church. ${ }^{9}$ Owing to its theatrical, musical and liturgical qualities, the liturgical play Tractus stellae has been attracting, for nearly the entire century, the attention of experts from various fields: liturgists, historians of literature, musicologists and theatre historians. It has been extensively written about from all those perspectives, in local and foreign literature. It was transcribed and translated into Croatian several times. ${ }^{10}$ Yet, it has missed the attention of art historians, despite the fact that it contains a mention of an "image" of the Virgin with the Child as one of the play's key theatrical props. I translate here the Latin term imago as "image" in quotes because it is not quite clear what media it refers to: painting or sculpture. Because of this and

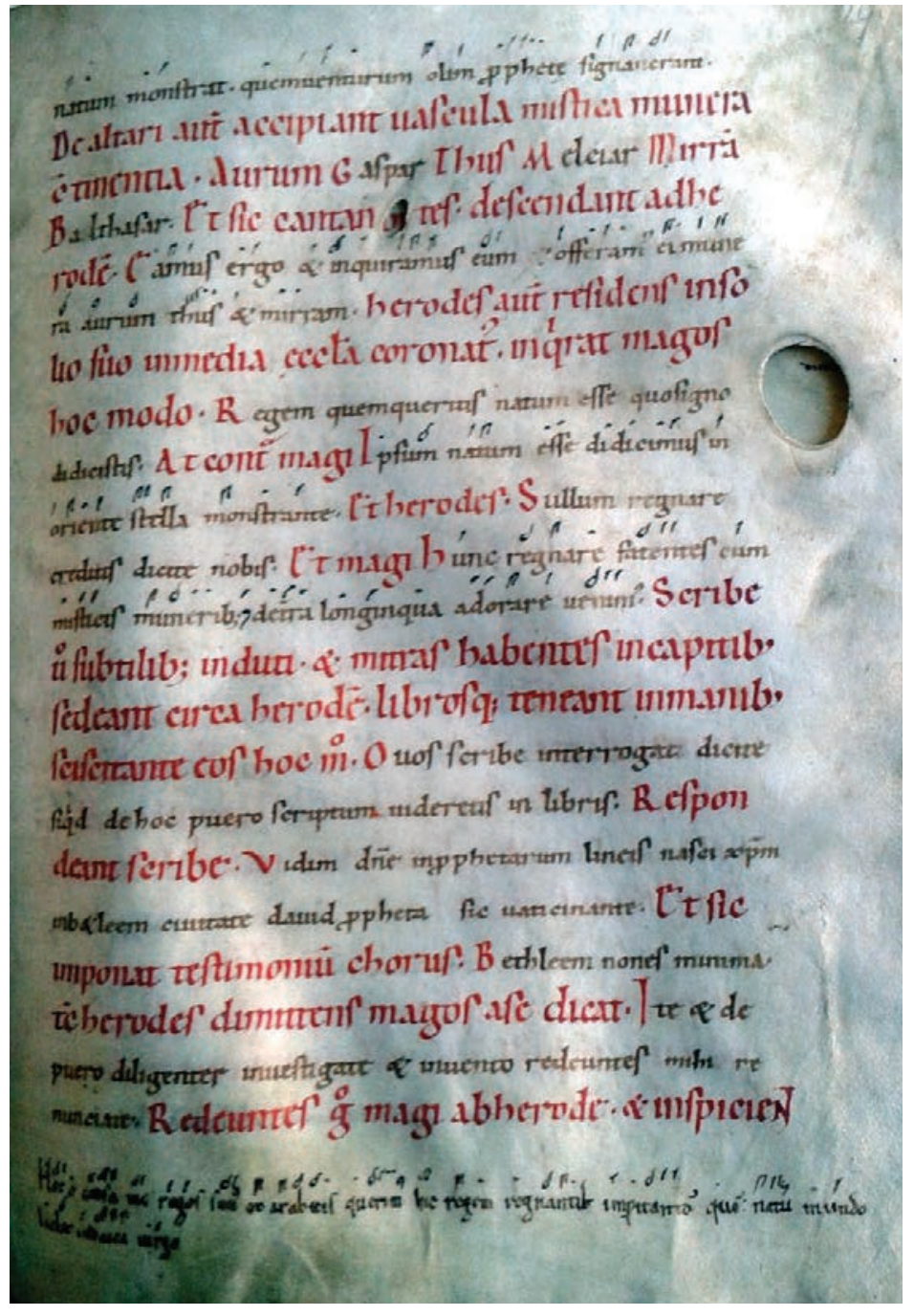

Fig. 2. Agenda Pontificalis, Tractus stellae, folio 29a, Bibliotheca Metropolitana, MR 165

p. 242-292. Afterwards, it was analysed by the American musicologist C. BROCKETT, Jr., A Previously Unknown "Ordo Prophetarum" in a Manuscript Fragment in Zagreb, in Comparative Drama, Vol. 27, No. 1, Continental Medieval Drama (Spring 1993), p. 114-127. According to him, the fragment belongs to the notation group of the Esztergom neume-writing family with four-line staff system, and is therefore also of Hungarian origin.

${ }^{7}$ According to F. FANCEV, op. cit., p. 6.

${ }^{8}$ This is how the play's title was originally recorded, although the Latin word originally written as stelle was later on transcribed by most authors as stellae. The latter form will be used hereinafter in the text. Fundamental study on this and other liturgical plays of the Medieval Church is contained in the work of K. YOUNG, The Drama of the Medieval Church, Oxford, 1951 (1st ed. 1933), Vol. 1, 2. Young analysed and presented manuscripts of all the versions known to him; however, the one from Zagreb was not among them.

${ }_{9}^{9}$ All the three Zagreb medieval liturgical plays with musical notation were referred to by Hana Breko at the $31{ }^{\text {st }}$ national convention of the American Association for the Advancement of Slavic Studies (AAASS), St. Louis, Missouri, USA 1999. Her paper was not published but it was concisely presented by W. A. EVERETT in a report on the aforementioned convention, in: Vijenac, 154 (2000), p. 32. The play was reconstructed on stage already in 1977, within the activities of Atelier de musique ancienne, Faculté de Musique, Université de Montréal - cf. D. SMOJE, Muzički $i$ dramatski elementi bogojavljenske igre Tractus stelle iz rukopisa Agenda pontificalis MR 165 Metropolitanske knjižnice u Zagrebu, in Arti musices, 10/2 (1979), p. 137; another staging of the play followed in 1994, in Zagreb, at St. Catherine Church, as part of collaboration between the French ensemble Venance Fortunat (artistic director: Anne-Marie Deschamps) and the students of the Master course of the Musical Youth in Grožnjan (artistic director: Katarina Livljanić). ${ }^{10}$ Cf. N. BATUŠIĆ, Scenska slika liturgijske drame iz obrednika zagrebačke stolne crkve, in Dani hvarskog kazališta 1, Split, 1975, p. 57-72. D. SMOJE, op. cit. p., 119-160 presents a complete Latin text with the reconstruction of the 


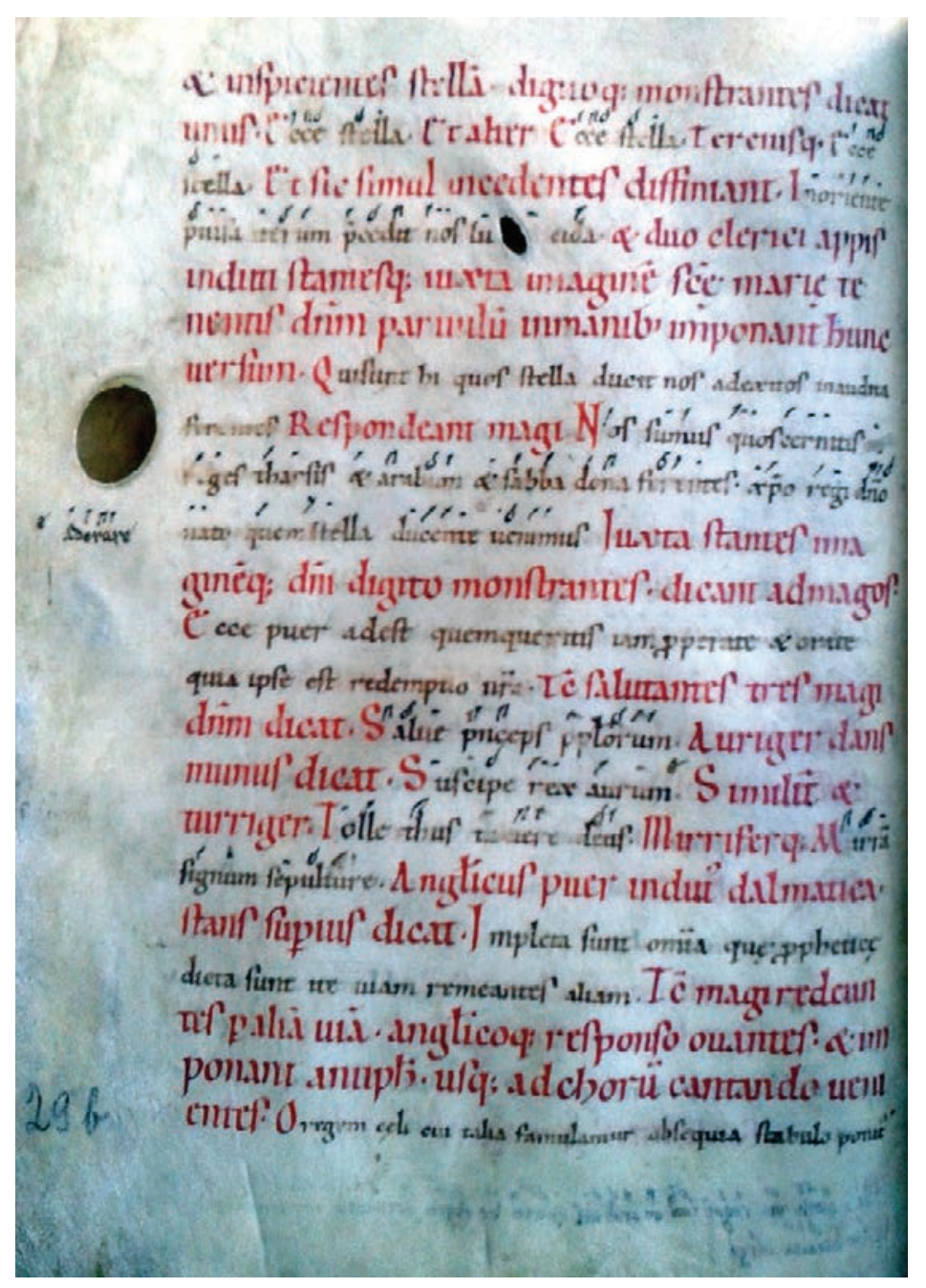

Fig. 3. Agenda Pontificalis, Tractus stellae, folio 29b, Bibliotheca Metropolitana, MR 165 other uncertainties, it seems necessary that art history, too, should take a look at this liturgical play - even more so because the earlier studies provided incorrect or insufficiently clear analyses of the details related to the aforementioned "image". For such a review there could hardly be a more suitable place than the jubilee proceedings devoted to the academician Igor Fisković, who dedicated a great deal of his research efforts precisely to solving different art historical puzzles of the (early) Romanesque period.

A liturgical play takes place, just as the liturgy itself does, in a church. On that liturgical "stage" there are certain elements which, by themselves alone, become convenient props for a play. If the play in question was performed at the Zagreb Cathedral, then the listed elements of its stage scenery may be viewed as a possible, although very succinct, description of the interior and the furnishings of the cathedral. Here, we need not be bothered by the fact that the same description would be applicable to any other church of that time in which the play may have been performed. On the contrary, we can consider it a more or less reliable evidence that the Zagreb church, already at an earliest stage after the foundation of the diocese, had everything needed to perform a liturgical play as a component of a particular liturgical ceremony. Naturally, the "image" of the Virgin with the Child is most interesting in this context, because it indicates something about the church that was true for all Romanesque churches: it was painted or furnished with paintings or sculptures. ${ }^{11}$ The question: "What might have the visual inventory of the Zagreb Cathedral looked like?" cannot be answered based on a single mention of an "image" of the Virgin with the Child in an Epiphany play that took place in the church. However,

notation. M. DEMOVIĆ, op. cit. p. 249-254 brings the Latin text - unfortunately with a lot of transcription errors - along with the Croatian translation. R. KATIĆIĆ, op. cit., p. 606-612 - gives the most correct transcript of the original text and a parallel translation into Croatian. Both authors include also two additional sentences in lower margins, each of which contains a neumatic notation originating from another, probably somewhat later hand. In Hungarian literature, particularly important study is that of G. KARSAI, Középkori vízkereszti játékok, Budapest, 1943, which describes and analyses the Zagreb play within the context of the related medieval liturgical plays. In the study, the integral texts of the Zagreb's and other plays were published, as well as a proposal for the reconstruction of the play in the Romanesque church in Györ. For the most recent transcript of the Latin text with corrections and amendments, see M. I. FÖLDVÁRY, Fragmenta Pontificalis antiqui Strigoniensis collata ex integris rubricis sex principalium fontium sceculorum XI-XVI., earundem synopsi atque nonnullis testibus referentiisque edidit, Budapest, 2006, p. 3-4. ${ }^{11}$ For more on this in general, see X. BARRAL i ALTET, Protiv romanike? Esej o pronađenoj prošlosti, Zagreb, 2009, pp. 72-79. [Contre l'art roman? essai sur une passé réinventé, Paris 2006, p. 78-87]. 
earlier theatrical analyses and reconstructions of the play and its stage scenery have sometimes contained conclusions and solutions that do not correspond with the current knowledge of either the history of the Zagreb's church architecture or the likely appearance of the "image" of the Virgin with the Child. Hence, this paper will briefly summarize the previous proposals for the reconstruction of the church interior and its stage props. Also, by providing a commentary of those proposals it will then indicate possible features of the church interior and the aforementioned "image" which, based on the knowledge of art-historical and other relevant sources, can be assumed to have been present in the Zagreb church of the late $11^{\text {th }}$ and then also the $12^{\text {th }}$ century. ${ }^{12}$

First, it should be said that we know almost nothing about the actual interior of the Zagreb cathedral church of that time. ${ }^{13}$ Therefore, it comes as a surprise that in a modern reconstruction of the play by D. Smoje the site of King Herod's throne is unequivocally located in the transept of the church. ${ }^{14}$ It is assumed, however, that the first Zagreb's cathedral was a single-nave building that ended in a semicircular or polygonal apse, meaning it could not possibly have had a transept. This cathedral church was built on Kaptol, probably in a short period of time, in the area of today's Cathedral. In fact, based on archaeological findings, it is highly likely that its location roughly coincided with that of the southern apse of the today's Cathedral, which, as a chapel, has always been dedicated to the Virgin Mary. Moreover, the Cathedral itself has also been dedicated to the Blessed Virgin Mary - in addition to St. Stephen the King. ${ }^{15}$ Hence, along with the relics of St. Stephen the King, the Zagreb church must also have had cult image (painting or statue) of the Blessed Virgin Mary. Yet, some important relics, such as a piece of St. Stephen the King's rib (latus) or St. Ladislaus the King's hand (manus), held in appropriate reliquaries, were recorded in the oldest inventory of the Zagreb Cathedral from 1394. ${ }^{16}$

${ }^{12}$ F. FANCEV, op. cit. 1-16, was first to outline the stage reconstruction of the liturgical play. After him, it was done
in a more extensive and daring manner by N. BATUSIĆ, op.cit. 52-72. The play was also reconstructed for the stage
by D. SMOJE, op. cit., p. 119-160, who quite correctly recognised that the name of the liturgical play could not be
translated as "dragging a star" or "pulling a star", but that the term "tractus" here, as in Gregorian chants of the
early Middle Ages, had a meaning similar to that of the term "rite" (ordo) or "ceremony" (officium). It is, therefore,
"a particularly festive part of the local ceremony for the Feast of Epiphany, resulting from the elaboration of the text
and music of the service performed on that day." (121). The physical "pulling of the star" itself, if there was any,
was not decisive in giving the play its title. We can not know what the star looked like - whether it was painted
with gold paint on a solid surface in the form of a shooting star or had a three-dimensional shape, illuminated by
some kind of artificial light - something that would technically be more difficult to perform but also more effective
from visual and scenery points of view. It is interesting that of all known versions of the liturgical play only the one from Zagreb contains the term tractus in the title.

${ }^{13}$ There is a crucial dilemma regarding this period of the Zagreb Cathedral: did already the founder of the diocese, King Ladislaus, build the first (probably small) church while the new, probably large one, was built shortly thereafter, in the 12th century, or is it the same building, or the so called Ladislaus' cathedral has never actually existed and the bishops used the parish church of St. Emeric until the Cathedral was built - cf. summarized in: I. K. TKALČIĆ, Crkva zagrebačka nekoč i sada, Zagreb, 1885, p. 4 - 6; A. DEANOVIĆ, Ž. ČORAK, Zagrebačka katedrala, Zagreb, 1988, p. 16-21; also L. DOBRONIĆ, Biskupski i kaptolski Zagreb, Zagreb, 1991, p. 13ff; in particular: N. KLAIĆ, Tobožnji Ladislavov "monasterium sancti Stephani regis" u Zagrebu, in Peristil, 24 (1981.), p. 35-40.

14 "The central scene takes place at the altar of St. Mary (ad altarem s. Mariae), which is on an elevated position and is connected by a few steps with the transept of the church." - D. SMOJE, op. cit., 129. The Three Wise Men (coming from different sides) meet in front of the altar of St. Mary, then descend the steps and come before Herod who is seated on the throne in the very transept of the church.

${ }^{15}$ A. DEANOVIĆ, Ž. ČORAK, op. cit., p. $18 \mathrm{ff}$.

${ }^{16}$ For the oldest inventories of the Zagreb Cathedral and the first known list of relics, see D. KNIEWALD, Najstariji inventari zagrebačke katedrale, in Starine, 43 (1951), 57-71. The relic of St. Stephen was recorded in Kniewald's transcript of the oldest inventory from 1394 under no. 90 and that of St. Ladislaus under no. 91. Both relics were again recorded in the inventory from 1474 (no. 13 and no. 14), and the record clearly shows that the relic in case of St. Stephen was a rib bone (costa lateris). The oldest inventory was also published by A. LUKINOVIĆ, Najstariji sačuvani imovnik zagrebačke katedrale (1394), in Croatica christiana periodica, 9 (1982), here p. 80-81. 
A new, apparently larger, cathedral was consecrated in 1217, during the reign of Hungarian King Andrew II. ${ }^{17}$ It is assumed that this church is depicted on the oldest preserved seal of the Zagreb Kaptol, from 1297. This was a three-nave church with three apses, of which the southern one was dedicated to the Virgin Mary. This did not change in the later Gothic cathedral - built after the Mongol invasion, at the time of Bishop Timotheus in the late $13^{\text {th }}$ century - and it has remained the same in the today's cathedral. Judging by the aforementioned seal (which is from a much later period and its documentary value is not entirely reliable) the pre-Mongol invasion church resembled the current cathedral in its architectural layout, though it was, naturally, executed in Romanesque style, with a hint of Gothic features. At its front, two bell towers can be discerned. ${ }^{18}$ There is nothing that would lead to the conclusion that the church had a transversal nave (transept).

Although there was probably no a transept in the new church, the Epiphany play did obtain a much larger stage in it. The church sanctuary with the main altar was presumably elevated, as were probably the apse chapels. In all likelihood, the church had a number of altars, including the altar of the Blessed Virgin Mary which, judging by the text of the liturgical play, was in the cathedral since its inception. ${ }^{19}$ Some researchers assume that the "image" of the Virgin with the Child itself was located on the St. Mary's altar, but there is no explicit evidence of this. ${ }^{20}$ In the liturgical play, the "image" was the main "prop" and the goal of the pilgrimage of the magi. ${ }^{21}$ At the end of their journey they came to the "image", beside which stood two clerics with pluvials ["Et duo clerici/c/appis induti

\footnotetext{
${ }^{17}$ I. K. TKALČIĆ, op. cit., p. 4.

${ }^{18}$ A. DEANOVIĆ, Ž. ČORAK, op. cit., p. 20-21.
}

${ }^{19}$ There are no direct data on the altars from the period before the restoration of the cathedral by bishop Timotheus in the second half of the 13th century: cf. I. K. TKALČIĆ, op. cit. 51. L. DOBRONIĆ, op. cit., p. 14, wrote, somewhat unclearly: "In addition to the main (in the pre-Mongol invasion cathedral perhaps the only) altar of St. Stephen the King, bishop Timotheus consecrated the altar of St. Ladislaus in the restored cathedral in 1275. Same as the current one, the Ladislaus' altar was located in the northern apse (between the main apse and sacristy). Nine years after the consecration of the altar of St. Ladislaus, Timotheus consecrated the altar of the Blessed Virgin Mary - on the 21st of August, 1285. The altar of the Blessed Virgin Mary has been located (until the present day) in the southern apse. Undoubtedly, by 1284, the building of that apse was completed, along with the painting of a cycle of frescoes depicting scenes from Mary's life of which, however, only a fraction was preserved in the southern part of the apse (the figure of Mary)." (p. 24). Yet, if the pre-Mongol invasion cathedral looked the way it was depicted on the seal from 1297, then it already had three apses and, most likely, also the altars that were consecrated at their original positions by bishop Thimoteus in the new Gothic church. Besides, there is a direct mention of the altar of St. Mary in the liturgical play - presumably the first explicit mention of an altar in the Zagreb church.

${ }^{20}$ F. FANCEV, op. cit., p.15: "...near the altar of Mary, where the image of Mary with Jesus in her hands marked the manger scene..."; D. SMOJE, op. cit., p. 130: "...the existing altar of St. Mary whose icon [!!!] suggests the location of the event."

${ }^{21}$ Image in this case replaces a performed manger scene that takes place in other versions of the play, in which midwives and shepherds say their parts of text. This, for instance, is the case with the liturgical play from Strasbourg, as well as the one from St-Benoit-sur Loire and many others - cf. K. YOUNG, op. cit., Vol. 2, pp. 66, 84ff. Due to the brevity of the description, the exact reconstruction of that part of the scene is not possible; however, in the manger scene, the divine characters are always replaced by a painting or a statue of the Virgin with the Child. Of all the examples of the Epiphany play, the "image" of the Virgin with the Child is expressly mentioned only in the plays from Nevers and Rouen and in this one, from Zagreb. The "image" is placed on an altar which is specially arranged for stage performance. In Rouen's play there is a specific mention of the altar of Holy Cross, beside which stand two clerics/witnesses dressed in dalmatics, who open the curtain in front of the image, reciting the words: Ecce puer adest... - cf K. YOUNG, op. cit., Vol. 2, p. 44ff; G. KARSAI, op. cit., p. $193 f f$ and, especially, I. H. FORSYTH, The Throne of Wisdom. Wood Sculptures of the Madonna in Romanesque France, Princeton, 1972, p. 55. Plays from Nevers and Rouen, which are dated back to the 11th century, are considered to be earliest, and exactly the aforementioned content elements make them closest to the one from Zagreb, although there are also considerable differences between them. The play from Rouen was analysed at length by H. ANZ, Die lateinischen Magierspiele, Leipzig, 1905, p. $23 \mathrm{ff}$. He believes that the altar of the Holy Cross, on which the image of the Virgin with the Child was placed for the occasion, was in the church nave, and that the two clerics/witnesses stood behind the altar, p. 33. 
stantesque iuxta imaginem sancte Marie tenentis dominum parvulum in manibus"] ${ }^{22}$ who, pointing to the "image”, recited: "Here is the boy whom you seek” [„Iuxta stantes imaginemque dum digito monstrantes dicant ad magos: Ecce puer adest quem queritis..."]. This paragraph of the play is the oldest indirect testimony to the existence of a cult object and artefact in the Zagreb church.

On the other hand, some researchers thought that the figure of the Child Jesus was actually a doll or a statue held by the two clerics; however, this leaves unclear what would then be Mary's role in the play. It seems that the conclusion about a doll/statue resulted from a wrong transcription, translation or understanding of the verbal form of the word tenentis in the aforementioned sentence, which certainly does not refer to the clerics, but to the Virgin. ${ }^{23}$

Here, the term imago could indicate a painting - made on a panel (icon), or a wall, but it could also indicate a statue or a relief of the Virgin with the Child. ${ }^{24}$ Probably it was a cult "painting", which was shown only on special occasions, rather than an altar painting (relief) that in the liturgical furnishing of the $11^{\text {th }}$ century was relatively rare. ${ }^{25}$ Also attractive is the idea that it may have been a wooden, silver plated and gilded statue of the Virgin with the Child in her lap-in accordance with the iconographic formula of sedes sapientiae, which became an increasingly important part of the Marian piety and cult precisely in the $11^{\text {th }}$ century. Such statues, according to I. H. Forsyth, were convincing representations of the Virgin and Son, and it is indisputable that they were used in liturgical plays. ${ }^{26}$ The two clerics in copes (pluvials) represented, as is usually said, midwives, who showed the child

${ }^{22}$ Cfr. M. I. FÖLDVÁRY, Fragmenta Pontificalis antiqui Strigoniensis ..., Budapest, 2006, p. 3. The author accepts the transcription of the word appis as "/c/appis" - which would mean that the clerics wore robes (pluvials), something that perhaps should be interpreted as a suggestion of the Old Testament Prophets. The first who transcribed the word appis in that manner was G. KARSAI, op. cit., p. 211.

${ }^{23}$ N. BATUŠIĆ, op. cit., p. 68: "In the works of some authors there is an assumption, regarding the other European versions of this play, that the clerics/midwives have perhaps held a painting of the Virgin with the Child while welcoming the Kings. In the case of Zagreb's stage picture, I would assume that this was rather a doll prop, since I interpret the text 'tenentis dominum parvulum in manibus' precisely by the existence of a prop as a necessary addition to the drama text." "... whereby the possible meaning of the Latin word 'imago' - statue - aids us in our assumption that this was a prop, wooden statue or doll, creating, in a most convincing and plastic manner, an impression of a new-born child." The author translated the verbal adjective tenentis, referring to the Virgin in genitive singular, as the first person plural, tenentes, as if it applies to the clerics - which is wrong. Later on, the author corrects his wrong interpretation, stating that "young [?] priests hold an image of the Virgin and the newborn Child in their hands" - N. BATUŠIĆ, Hrvatsko srednjovjekovno kazalište, in Hrvatska $i$ Europa - kultura, znanost, i umjetnost; Srednji vijek i renesansa, E. HERCIGONJA (ed.), Zagreb, 2001, p. 393. While Batušić's original conclusion about the boy doll stems from a completely wrong translation of the verbal form tenentis, Demovićs oversight results from an incorrect transcription of this verbal form - as tenentes: Et duo clerici appis induti stantesque iuxta imaginem sanctae Mariae tenentes Dominum parvulum in manibus inponant hunc versum. Translation: "And two winged clerics, standing before the image of Mary, hold in their hands a statue of Child Jesus and start reciting this verse:...", M. DEMOVIĆ, op. cit., p. 253. The same author, however, in the description of the play says that: "two clerics, who are supposed to represent angels, appear holding in their hands the image of Mary with little Christ" [!!!] (p. 248). The correct transcription of this part of the text is made by Dujka Smoje and Radoslav Katičić who, naturally, do not mention the boy doll in the translation of the text.

${ }^{24}$ Cf. H. BELTING, Bild und Kult. Eine Geschichte des Bildes vor dem Zeitalter der Kunst, Munich, 1990, p. 335. Belting equated the term imago in the Epiphany play with a statue of the Blessed Virgin with the Child, while using in the same description the term image: "Actors who embodied the Kings would step on the choir area, where in front of a statue of the Virgin Mary a curtain would open, and they were shown an image, with an exclamation: here is the child that you are looking for!" [bolded by M.P.].

${ }^{25}$ For the differences, cf. H. BELTING, op. cit., p. 496-505.

${ }^{26}$ The function of the wooden statue of the Virgin with the Child in a liturgical drama, and primarily in the liturgical play Officium stellae, is extensively discussed by I. H. FORSYTH, op. cit., pp. 49-60, with further literature on the subject. 
in the Virgin's lap to the Kings and the faithful. ${ }^{27}$ The two clerics stood iuxta imaginem - near or next to the "image", probably on both sides. An angelic boy would appear above the "image" [Angelicus puer indutus dalmatica stans superius], declaring that the words of the prophets were fulfilled, and warning the Kings not to return to Herod but to take a different way back, which they do [Impleta sunt omnia que prophetice dicta sunt ite viam remeantes aliam]. ${ }^{28}$ The "image" was perhaps veiled (as in liturgical play from Rouen) until the Kings appeared in front of it. Then it would be unveiled, along with a boy dressed as an angel, who, together with the two clerics/witnesses, served to enhance the semantic dimension of the "image" in accordance with the liturgical scenery, i.e. the iconography of the adoration of the magi. Referring to the text of a liturgical play from Nevers (11 ${ }^{\text {th }}$ century), I. L. Forsyth says: "Moreover, the use of imaginem in the singular indicates that it is a combined image, Mother and Son together, as they would be in sedes sapientiae formula, making it likely that the "image" was a statue of Mary with the Child in her lap, presumably placed on the altar where the midwives are stationed. Imago is a word commonly used for such statues of the Madonna, although it might also refer to a relief, as in a retable. In view of the texts cited below, however, the latter possibility seems precluded." 29 Perhaps the text of the Zagreb liturgical play, of which I. H. Forsyth was not aware, would have further strengthened her argument on the use of wooden (silver plated and gilded) statue of the Virgin with the Child in line with sedes sapientiae inconographic formula in the liturgical play of the Three Kings.

Indeed, if we return now to the oldest inventory of the Zagreb Cathedral from 1394, we will find - at the very beginning of the list of precious relics and reliquaries - a very significant reference: Item est una imago beate Virginis in sinu filium suum habens deauratam ["should be deaurata“: comment by A. Lukinović], in ecclesia, quam sunt alique certe reliquie. ${ }^{30}$ It is, therefore, an "image" of the Blessed Virgin holding her son on her lap - and the image is gilded. At the time of the first inventory's creation, the image was in the church, along with some other sacred relics. Based on this record, a statue of sedes sapientiae type could come to mind. However, it was probably the same "image" that was again recorded in a much later inventory from 1474: Item una ymago beate virginis de argento, deaurata, parua, super uno pede argenteo quadrata. ${ }^{31}$ This commentary suggests that the "image" was made of silver, that it was of rectangular shape (perhaps a relief), that it was gilded, but had a silver foot, and that it was not large. ${ }^{32}$ Since we lack any comparative reference, we cannot know what the person who compiled the inventory meant by the "small". In even later inventories (which are incomplete) the "image" no longer appears. With some boldness and a necessary dose of caution we could assume that this in fact is the Romanesque cult "image" of the Virgin with the Child that was used in the liturgical play Tractus stelle.

These considerations that hopefully provide at least some clues toward the nature and purpose of the image in the Zagreb's Epiphany play should be concluded with a simple statement, i.e. that the scenery of the play does not necessarily imply a specific site such as Esztergom, Győr, Zadar or

\footnotetext{
${ }^{27}$ M. DEMOVIĆ, op. cit., p. 253, states that the clerics had wings and that they impersonated angels. Midwives [obstetrices] appear in a number of texts; they were probably represented by robed clerics. Cf. I. H. FORSYTH, op. cit., p. 55.

${ }^{28}$ The boy also appears in the aforementioned play from Rouen - cf. K. YOUNG, op. cit., p. 44; G. KARSAI, op. cit., p. 194.

${ }^{29}$ I. H. FORSYTH, op. cit., p. 55.

${ }^{30}$ D. KNIEWALD, Najstariji inventari zagrebačke katedrale (op. cit.), p. 65, nr. 94 i A. LUKINOVIĆ, op. cit., p. 80.

${ }^{31}$ D. KNIEWALD, Najstariji inventari zagrebačke katedrale (op. cit.), p. 75, nr. 17.

${ }^{32}$ That this is the same "image" as the aforementioned is believed, too, by D. KNIEWALD, Najstariji inventari zagrebačke katedrale (op. cit.), p. 79.
} 
Zagreb's church. The play primarily reflects a universally applicable model of the scenery of liturgical rites - one that could be obtained in any church building of some importance, including the one in Zagreb. ${ }^{33}$ On the other hand, the "image" of the Virgin with the Child, which had a crucial role in the play / liturgy, was probably an object of special veneration precisely in the Zagreb Cathedral - identical in significance to the main relics of the church, something much more than a mere stage prop. Its prominent significance in the performance of the Epiphany play undoubtedly testifies to an important aspect of the use of visual artefacts in the Zagreb Cathedral at the end of the $11^{\text {th }}$ or beginning of the $12^{\text {th }}$ century. ${ }^{34}$

\section{TRACTUS STELLAE: „SLIKA“ BOGORODICE S DJETETOM U ZAGREBAČKOJ KATEDRALI 11. / 12. ST.}

U najstarijem pontifikalnom obredniku zagrebačke katedrale (Agenda pontificalis, Metropolitanska knjižnica Zagreb, MR 165), kojega se nastanak datira u kasno 11. st., zapisan je među liturgijskim obredima uz blagdan Bogojavljenja crkveni obred Tractus stelle, kao liturgijska predstava koja se ubraja među najvažnije za povijest te obredne igre uopće u tradiciji zapadnoga bogoslužja i crkvenih predstava. O njoj se pisalo sa stajališta liturgike, povijesti glazbe, kazališta i književnosti. U nekoliko navrata ona je transkribirana i prevedena na hrvatski jezik. Kao ključni scenski rekvizit u igri se navodi "slika“ Bogorodice s djetetom, kojoj je posvećen ovaj rad. Latinski pojam imago ovdje se prevodi kao "slika“ u navodnicima jer nije sasvim jasno na koji se medij on odnosi: slikarstvo ili skulpturu. U svakom slučaju "slika" Bogorodice s djetetom ukazuje na to da je koncem 11. st. zagrebačka katedrala raspolagala mobilnim slikama ili skulpturama. Sama je "slika“ u obrednoj igri cilj hodočašća triju kraljeva. Na kraju svoga puta oni dolaze do "slike" pokraj koje stoje dva klerika s plaštevima koji, pokazujući prstom na "sliku", recitiraju: „Ovdje je dječak kojeg tražite“. Neki su istraživači smatrali da je lik djeteta Isusa bio zapravo lutka ili kip koji u rukama drže dvojica klerika, no taj zaključak o lutki-kipu proizlazi iz pogrešnog prijepisa, prevođenja, odnosno razumijevanja glagolskoga oblika tenentis u odgovarajućoj rečenici igre [Et duo clerici/c/appis induti stantesque iuxta imaginem sancte Marie tenentis dominum parvulum in manibus], koji se nikako ne odnosi na klerike, već na Bogorodicu.

Pojam imago mogao je značiti sliku na dasci (ikonu) ili na zidu, a mogao je značiti i kip, odnosno reljef Bogorodice s djetetom. Vjerojatno se radilo o kultnoj „slici“, koja se vjernicima pokazivala samo u posebnim prigodama, a ne o oltarnoj slici (reljefu), kakve su u liturgijskoj opremi 11. st. relativno rijetke. Privlačna je i pomisao da se radilo o drvenom, možda srebrom obloženom i pozlaćenom kipu Bogorodice s djetetom u krilu prema ikonografskoj formuli sedes sapientiae, dakle o tipu "slike" koji je upravo tijekom 11. st. dobivao sve veći značaj u pobožnosti i kultu. U najstarijem inventaru zagrebačke katedrale iz 1394. godine na početku popisa dragocjenih relikvija i relikvijara zapisana je doista una imago beate Virginis in sinu filium suum habens ... Riječ je, dakle, o "slici" Blažene Djevice koja u krilu drži svoga sina i koja je bila pozlaćena. U doba izrade prvoga popisa ona se nalazila u crkvi, zajedno s nekim drugim svetim relikvijama. Na temelju tog zapisa moglo bi se pomišljati na kip tipa sedes sapientiae. Međutim, vjerojatno je ista "slika" zabilježena i u znatno kasnijem inventaru iz 1474.: Item una ymago beate virginis de argento, deaurata, parua, super uno pede argenteo quadrata. Iz te zabilješke slijedi da je "slika“" bila od srebra, da je bila pravokutna i da je bila pozlaćena, te da je imala podnožje od srebra, ali da nije bila velika. S dopuštenom dozom smjelosti i nužnom dozom

\footnotetext{
${ }^{33}$ Cf. I. H. FORSYTH, op. cit., p. 54.

${ }^{34}$ In this context, A. DEANOVIĆ, op. cit., p. 19, describes the first Zagreb's bishop Duh, somewhat emphatically, as the originator of liturgical rites and as a learned Benedictine of refined taste and broad culture, and admires how "the small Ladislaus' church was meaningfully and densely filled up with liturgical ceremonies and church performances intended for it by this important bishop!"
} 
opreza mogli bismo pretpostaviti da je ovdje riječ o istoj romaničkoj kultnoj "slici“ (ikoni, reljefu ili kipu) Bogorodice s djetetom koja se rabila u obrednoj igri Tractus stelle. U navedenom zapisu inventara oznaka parua ukazivala bi na to da je "slika" malog formata. Budući da nemamo nikakvu komparativnu referenciju ne možemo znati što je popisivaču ta oznaka značila. U svakom slučaju riječ je o pokretnoj „slici“ koja je sve do početka 15. st. bila u katedrali.

„Slika" Bogorodice s djetetom koja je imala presudnu ulogu u predstavi-obredu Tractus stellae, vjerojatno je bila predmet osobitog štovanja u zagrebačkoj katedrali, po značenju istovjetna glavnim relikvijama crkve, među kojima je i popisana u navedenim inventarima - što je znatno više od pukog kazališnog rekvizita. Bez obzira da li je ta "slika" ona koju bilježe kasniji inventari, njezin ključni značaj u odvijanju bogojavljenske igre nedvojbeno svjedoči o jednom važnom aspektu uporabe likovne umjetnosti u zagrebačkoj stolnoj crkvi koncem 11. ili početkom 12. stoljeća.

Ključne riječi: Agenda pontificalis Zagreb, Tractus stellae, slika Bogorodice s djetetom, Sedes sapientiae 